\title{
Bonamia-like parasite found in the Suminoe oyster Crassostrea rivularis reared in France
}

\author{
Nathalie Cochennec*, Tristan Renault, Pierre Boudry, Bruno Chollet, André Gerard
}

IFREMER, Laboratoire de Génétique, Aquaculture et Pathologie, BP 133, Ronce les Bains, F-17390 La Tremblade, France

\begin{abstract}
Considering the economic importance of the Pacific oyster Crassostrea gigas to the French shellfish industry, the appearance of major diseases in this species could cause dramatic decreases in production. Suminoe oysters, of the non-indigenous species Crassostrea rivularis (Gould), were introduced into France to test their ability to adapt to local conditions. These oysters were imported after careful examination, and were maintained in laboratory quarantine. Some mortalities occurred 7 mo after importation. Histological and electron microscope examinations of 9 dead specimens revealed a parasite presumed to be a Bonamia-like protozoan. This is the first report concerning a parasite of the genus Bonamia in a species belonging to the genus Crassostrea. Thus, $C$. rivularis is not considered to be a suitable substitute for C. gigas in France.
\end{abstract}

KEY WORDS: Crassostrea rivularis S Suminoe oyster $\cdot$ Bonamiosis $\cdot$ Bonamia-like parasite

\section{INTRODUCTION}

The Pacific oyster Crassostrea gigas was introduced into France from Japan in the late 1960s after the disappearance of the Portuguese oyster $C$. angulata due to iridoviral infections (Comps \& Duthoit 1976, Comps et al. 1976, Grizel \& Héral 1991). Considering the economic importance of the Pacific oyster to the French shellfish industry, the appearance of major diseases in this species could be catastrophic. In this context, the search for species that could replace $C$. gigas was initiated by IFREMER at La Tremblade (CharenteMaritime, France). Non-indigenous species, such as $C$. virginica, $C$. sikamea and $C$. rivularis, have been imported following careful examination according to ICES (International Council for the Exploration of the Sea) rules, and maintained in quarantine facilities. Their ability to adapt to local rearing conditions was tested with experiments on comparative growth and susceptibility to known local parasites.

As part of this research, Crassostrea rivularis was imported from the USA in 1994. Before the importation of live oysters, histological examinations were per-

·E-mail: ncochenn@ifremer.fr formed on 30 fixed specimens to check for the presence of lesions or pathogens. In the absence of any recognised pathogens, 100 adult $C$. rivularis oysters were imported from New Jersey to the La Tremblade laboratory. These oysters were maintained in strict quarantine.

Seven months after introduction, some mortalities occurred in quarantine. Histological examinations were performed and revealed the presence of an intracellular protozoan parasite in connective tissues of 9 dead specimens. In order to investigate further, the parasite was purified and examined using an electron microscope. Ultrastructure analysis suggested that the protozoan might belong to the genus Bonamia. This paper is the first report of the presence of a Bonamialike parasite in C. rivularis introduced to and reared in France. Furthermore, it is the first report of a Bonamialike parasite in any Crassostrea species.

\section{MATERIALS AND METHODS}

Oysters. 30 fixed and 100 live adult Crassostrea rivularis (Gould), from the same stock, were provided by Haskin Shellfish Research Laboratory (Rutgers University, New Jersey, USA). The fixed specimens were 
received in January 1994 and were examined histologically at the IFREMER laboratory following ICES rules. Live oysters were received in July 1994 and were kept in quarantine. The quarantine system uses chlorine treatment for outlet water, but no treatment is applied to inlet water. Inlet water comes from the Marennes Oleron basin, where bonamiosis is present on the flat oyster Oshea edulis.

Histological examination. After the oysters were removed from their shells, they were sectioned sagittally. Half of each was placed in Davidson's fluid, and the other half in buffered formalin, according to Carson et al. (1973). The samples fixed in Davidson's fluid were dehydrated through an ascending ethanol series, cleared in xylene and embedded in paraffin wax. Blocks were sectioned at 3 to $4 \mu \mathrm{m}$ thickness, stained with hematoxylin and eosin (H/E) and then examined for lesions and pathogens. The samples in Carson's fixative were examined by electron microscopy (see below). Heart smears were also performed on the dead oysters. These were stained with a Hemacolor kit (Merck) and were then examined by microscope for the presence of parasites.

Electron microscopy. Pieces of gill and digestive gland were collected from the oysters stored in Carson's fixative. They were rinsed in cacodylate buffer and fixed in $2.5 \%$ glutaraldehyde in $0.2 \mathrm{M}$ cacodylate buffer at a pH of 7.2 , then post-fixed in $1 \%$ osmium tetroxide in the same buffer. The specimens were then cleared in propylene oxide and embedded in Epon resin. Sections of $1 \mu \mathrm{m}$ were taken for light microscopy and stained in $2.5 \%$ toluidine blue in $1 \%$ aqueous sodium borate solution. Ultra-thin sections were made using copper grids and double stained with uranyl acetate and lead citrate. These were then examined in a Jeol JEM 1200 EX transmission electron microscope.

Pellets of purified parasites were fixed in $2.5 \% \mathrm{glu}-$ taraldehyde in $0.2 \mathrm{M}$ cacodylate buffer and post-fixed with $1 \%$ osmium tetroxide in the same buffer. The pellets were placed in low melting point agarose, dehydrated in an ethanol series and then treated following classical techniques for electron microscopy.

Purification. Heart smears of dead oysters were prepared and examined by microscope to determine infection level. Three strongly infected oysters were selected for purification. Parasites were purified according to the protocol of Mialhe et al. (1988). After homogenization of all organs except the adductor muscle, the parasites were concentrated by differential centrifugation on sucrose gradients and then separated by isopyknic centrifugation on a Percoll gradient. Finally, the purified parasites were resuspended in filtered sea water $(0.22 \mu \mathrm{m})$ and counted using a Malassez-cell haemocytometer.

\section{RESULTS}

\section{Histological examination}

Parasitic infections were found in connective tissues of 9 dead Crassostrea rivularis which had been reared in the quarantine facilities of the IFREMER laboratory at La Tremblade. Histological sections revealed the presence of numerous spherical basophilic organisms, 2 to $3 \mu \mathrm{m}$ in diameter, with a characteristic non-central large nucleus. The parasites were located in the hemocyte cytoplasm (Fig. 1). The infected cells typically accumulated in the vascular sinuses around the stomach, intestine and digestive gland. However, infected hemocytes were observed in all connective tissues. A characteristic histological feature of the infected oysters was the disassociated appearance of connective tissues which were infiltrated by groups of infected hemocytes (Fig. 2).
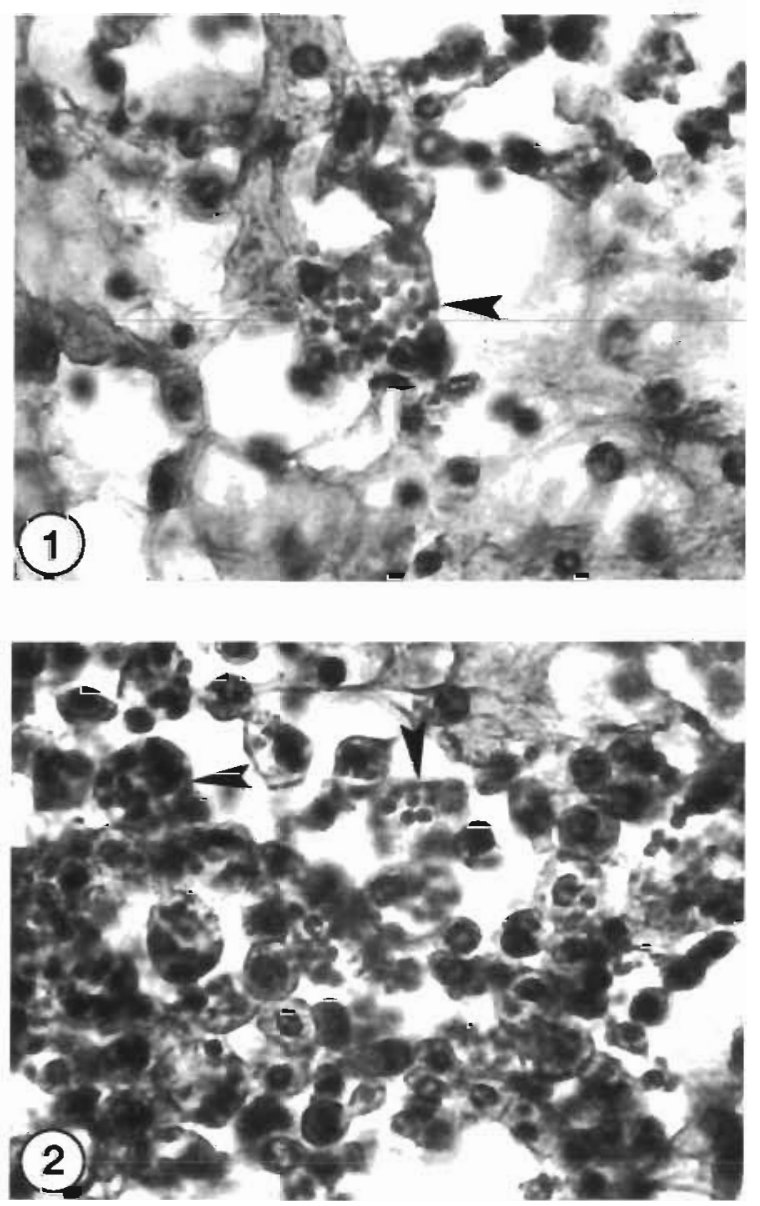

Figs. 1 \& 2. Crassostrea rivularis with Bonamia-like infection. Hematoxylin/eosin stain. Light microscopy $(\times 1000)$. Fig. 1. Numerous parasites located in hemocyte cytoplasm (arrow). Fig. 2. Connective tissue infiltrated by groups of infected hemocytes (arrows) 


\section{Electron microscope examination}

Organisms were found in hemocytes, in gills and within the digestive gland. Infected hemocytes generally contained several parasitic cells. These were sometimes enclosed within a large vacuole. Occasionally, parasitic cells were visible in the cytoplasm; these were not delimited by a vacuolar membrane (Figs. 3 \& 4). The structure of some hemocytes was only slightly affected, while others were more profoundly altered and displayed vacuolization (Fig. 4).

After purification, the parasite was visible as a spherical or ovoid cell of about 3 to $5 \mu \mathrm{m}$ in diameter (Fig. 5). It was bound by a unit membrane as well as a plasmalemma of similar thickness to that of the host cell (Fig. 6). A distinct peripherally located nucleolus was sometimes present. The nuclear envelope consisted of an inner and an outer membrane, with some nuclear pores. The cytoplasm was moderately dense and contained 1 or 2 mitochondria. These mitochondria were variable in size $(0.5$ to $1.5 \mu \mathrm{m}$ in diameter) and displayed short cristae pointing toward the matrix, which was electron-lucent (Fig. 6). Haplosporosomes were characteristically present, scattered throughout the cytoplasm. The haplosporosomes displayed 2 parallel layers of membranous appearance, one external and the other internal, embedded in a very electron-dense material (Fig. 7). Occasionally a dense body of about $0.8 \mu \mathrm{m}$ was present. Numerous free ribosomes could be observed in the cytoplasm, as well as a few small citernae of the endoplasmic reticulum.

\section{DISCUSSION}

This study reports the presence of a protozoan infection in the connective tissues of Crassostrea rivularis found at the IFREMER laboratory in La Tremblade (Charente Maritime, France). The infected oysters were maintained in quarantine facilities where chlorine treatment prevents the escape of pathogens. However, without inlet water treatment, the hypothesis that Bonamia was transmitted to the experimental oysters from neighboring waters which are endemic for bonamiosis is strongly supported.

The structure and the histological location of the detected parasite are characteristic of parasites belonging to the genus Bonamia. Comparison between infected tissues of Crassostrea rivularis and the European flat oyster Ostrea edulis parasitized by Bonamia ostreae reveal no morphologic differences at the light or electron microscope level. In order to confirm that the parasite is the same, it was first necessary to isolate and purify it. The use of the $B$. ostreae purification protocol enabled the parasites found in C. rivularis to be purified, further highlighting their similarity. These purified cells displayed no difference from $B$. ostreae at the ultrastructural level either.

Morphological features of the parasite found in Crassostrea rivularis are in agreement with those described by Pichot et al. (1980) and Comps et al. (1980) for the species Bonamia astreae. They also agree with those of Bonamia sp. in Tiostrea lutaria (Dinamini et al. 1987). The only differences found between these 2 presumed species of Bonamia are ultrastructural differences: number of haplosporosomes and large globules, morphology of mitochondria and nuclear/cytoplasmic ratio.

It is also of note that location and morphological structure of the parasite found here in Crassostrea rivularis are not in agreement with those previously described by Farley et al. (1988) for 2 species of disease-causing crassostreid parasites, which they assigned to the genus Mikrocytos: $M$. mackini in Crassostrea gigas from British Columbia (Canada) and $M$. roughleyi in Saccostrea commercialis from Australia. Histopathologically, $M$. mackini is characterized by acute inflammatory abscesses which remain focal until the oyster dies. Electron microscopy has demonstrated that organelles resembling haplosporosomes only occur at one stage in Mikrocytos. The haplosporosome-like organelles often tend to be elongated and contain layers of membranes. The internal structure of these organelles is not nearly as dense as that seen in Bonamia or other haplosporidans. In contrast with Bonamia, no clear demonstration of mitochondria has been achieved in Mikrocytos. Mikrocytos is always associated with focal abscesses and occurs in crassostreid oysters whereas Bonamia is always associated with generalized infections and has only been reported in ostried oysters up until now (Farley et al. 1988).

All the characteristics of the parasite detected indicate an infection by the parasite Bonamia ostreae in an endemic area. Control oysters which were examined before importation, following ICES rules, did not contain detectable parasites and the mortalities appeared only after 7 mo in quarantine.

Previous controlled introductions of healthy stocks of Ostrea chilensis from Chile and Ostrea angasi from Australia were followed by Bonamia ostreae infection in locations along the French coasts where $B$. ostreae is endemic and naturally infects the local $O$. edulis (Grizel et al. 1983, Bougrier et al. 1986). In this study we report the presence of a parasite clearly related to the genus Bonamia but in an oyster species belonging to the genus Crassostrea.

Crassostrea rivularis (Gould, 1861) is synonymous with C. ariakensis (Wakiya) (Torigoe 1981). This species occurs naturally in Japan (Torigoe 1981), Pakistan and India (Ahmed 1971), and China (Zhuang 1992). It 


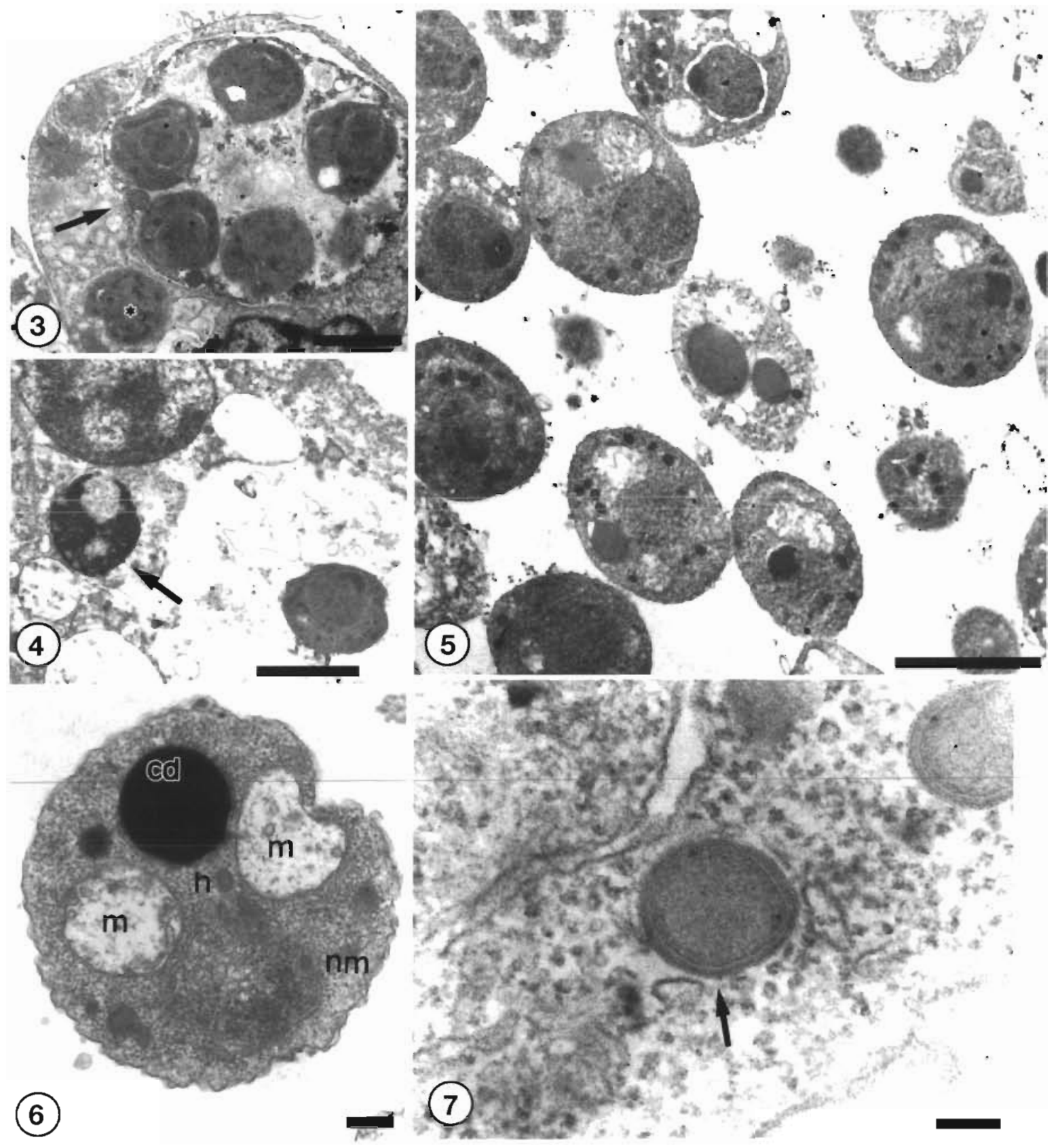

Figs. 3 to 7. Crassostrea rivularis with Bonamia-like infection. Electron microscopy. Fig. 3. Naturally infected oyster hemocyte showing numerous parasites enclosed within a large vacuole (arrow) and one (asterisk), in the cytoplasm, not delimited by a vacuole membrane. Fig. 4. Infected hemocyte showing altered parasite (arrow) in the cytoplasm. Fig. 5. Ultrathin section of purified parasites. Scale bar $=2 \mu \mathrm{m}$. Fig. 6. Parasite showing nuclear membrane $(\mathrm{nm})$, haplosporosome (h), mitochondria (m), and dense body (cd). Scale bar $=500 \mathrm{~nm}$. Fig. 7. Detail of hap-

losporosome-like body (arrow). Scale bar $=200 \mathrm{~nm}$

is of commercial importance in China (Yongjia et al. 1995) and has also been introduced from Japan to the USA, where it is cultivated on the west coast (Langdon \& Robinson 1991). Its gametogenic cycle makes it a good candidate for a 'summer' oyster (Perdue \& Erickson 1984). Although 'Ostrea rivularis' is mentioned in a recent paper on oysters from southern China (Yongjia et al. 1995), the placement of the oysters we studied in the genus Crassostrea is certain. DNA studies based on partial $28 S$ rRNA gene and on mitochondrial 16S IRNA gene sequences confirm the close relationship between C. rivularis and other members of the genus Crassostrea (Littlewood 1994, O'Foighil et al. 1995) These are all non-incubatory oysters and hybridiza- 
tions may occur within the genus as has been shown with C. gigas and C. rivularis (Allen \& Gaffney 1993). Such hybrids have been produced recently in our laboratory at La Tremblade.

Crassostrea gigas has been recognized by the European Commission as a non-carrier species for the parasites Bonamia ostreae and Marteilia refringens (93-169-CEE). Moreover, Renault et al. (1995) obtained no proliferation of $B$. ostreae in $C$. gigas experimentally challenged by the parasite, confirming the previous observations obtained by epidemiological observation. A comparative study of the resistance of C. gigas, C. rivularis and their inter-specific hybrids to parasites of the genus Bonamia could be of great interest for the understanding of host-parasite relationships in bivalves.

Our report demonstrates the possible susceptibility of Crassostrea rivularis to a Bonamia-like parasite. Thus, C. rivularis is no longer considered as a potential substitute for $C$, gigas in France. This study also underlines the potential danger of introducing nonindigenous species of bivalves for rearing without sufficient control protocols.

Acknowledgements. We thank S. K. Allen Jr for providing the specimens of Crassostrea rivularis from the hatchery of the Haskin Shellfish Research Laboratory. We are also grateful to $H$. R. McCombie for helpful comments. This work was supported by the Région Poitou-Charentes (Convention 95/ RPC-R-57 'Génétique').

\section{LITERATURE CITED}

Ahmed M (1971) Oysters of West Pakistan. Pak. J Zool 3: $229-236$

Allen SK, Gaffney PM (1993) Genetic confirmation of hybridization between Crassostrea gigas (Thunberg) and Crassostrea rivularis (Gould). Aquaculture 13:291-300

Bougrier S, Bachère E, Grizel H (1986) Ostrea angasi. An acclimatization to French coasts. Aquaculture 58:151-154

Carson FL, Martin JH, Lynn JA (1973) Formalin fixation for electron microscopy a re-evaluation. Am J Clin Pathol 59: 365-373

Comps M, Bonami JR, Vago C, Campillo A (1976) Une virose de l'huitre portugaise (Crassostrea angulata Lmk). C R Hebd Séances Acad Sci, Ser D, Sci Nat 282:1991-1993

Comps M. Duthoit JL (1976) Infection virale associée à la 'maladie des branchies' de l'huitre portugaise Crassostrea angulata Lmk. C R Hebd Séances Acad Sci, Ser D, Sci Nat

Editorial responsibility: Albert Sparks,

Seattle, Washington, USA
283:1595-1596

Comps M. Tigé G, Grizel H (1980) Recherches ultrastructurales sur un protiste parasite de l'huitre plate Ostrea edulis L. C R Acad Sci 290(D):383-384

Dinamini P, Hine PM, Jones JB (1987) Occurrence and characteristics of the haemocyte parasite, Bonamia sp., in the New Zealand dredge oyster Tiostrea lutaria. Dis Aquat Org $3: 37-44$

Farley CA, Wolf PH, Elston RA (1988) A long term study of 'microcell' disease in oysters with description of a new genus, Mikrocytos (G. N.), and two new species, Mikrocytos mackini (sp. N.) and Mikrocytos roughleyi (sp. N.). Fish Bull US 86:581-592

Grizel $H_{1}$ Comps M, Raguennes D, Le Borgne Y, Tigé G, Martin AG (1983) Bilan des essais d'acclimatation d'Ostrea chilensis sur les côtes de Bretagne. Rev Trav Inst Pêches Marit 46:209-225

Grizel H, Héral $M$ (1991) Introduction into France of the Japanese oyster (Crassostrea gigas). J Cans Int Explor Mer 47:399-403

Langdon CJ, Robinson A (1991) Development of the commercial aquaculture of the Suminoe oyster (Crassostrea rivularis). J Shellfish Res 10(1):238-240

Littlewood DTJ (1994) Molecular phylogenetics of cupped oysters based on partial $28 \mathrm{~S}$ rRNA gene sequences. Mol Phylogenet Evol 3(3):221-229

Mialhe E, Bachère E, Chagot D, Grizel H (1988) Isolation and purification of the protozoan Bonamia ostreae (Pichot and coll., 1980), a parasite affecting the flat oyster, Ostrea edulis L. Aquaculture 71:293-299

O'Foighil D, Gaffney PM, Hilbish TJ (1995) Differences in mitochondrial $16 \mathrm{~S}$ ribosomal gene sequences allow discrimination among American [Crassostrea virginica (Gmelin)] and Asian [C gigas (Thunberg), C. ariakensis Wakiyal oyster species. J Exp Mar Biol Ecol 192:211-220

Perdue JA, Erickson G (1984) A comparison of the gametogenic cycle between the Pacific oyster Crassostrea gigas and the Suminoe oyster Crassostrea rivularis in Washington State. Aquaculture 37:231-237

Pichot Y, Comps M, Tige G, Grizel H, Rabouin MA (1980) Recherches sur Bonamia ostreae gen. n., sp. n., parasite nouveau de l'huitre plate, Ostrea edulis L. Rev Trav Inst Pêches Marit 43:131-140

Renault T, Cochennec N, Grizel H (1995) Bonamia ostreae, parasite of the European flat oyster, Ostrea edulis, does not experimentally infect the Japanese oyster, Crassostrea gigas. Bull Eur Assoc Fish Pathol 15(3):78-80

Torigoe K (1981) Oysters in Japan. J Sci Hiroshima Univ, Ser B, Div 1 (Zool) 29:291-418

Yongjia Z, Munday BL, Handlinger J (1995) Mass mortalities of flat oysters (Ostrea rivularis) associated with a bloom of Prorocentrum sp. in the port of Zhanjiang, South China. Bull Eur Assoc Fish Pathol 15(2):61-63

Zhuang Q (1992) Research on marine bivalves in the People Republic of China. Am Malacol Bull 9(2):207-215

Submitted: August 15, 1996; Accepted: May 14, 1998

Proofs received from author(s): October 21, 1998 